\title{
Minerals multi-element analysis and its relationship with geographical origin of artisanal Mexican goat cheeses
}

\author{
Erasmo HERMAN-LARA ${ }^{1}$, Daniel BOLÍVAR-MORENO², Víctor Manuel TOLEDO-LOPEZ², \\ Luis Fernando CUEVAS-GLORY², Mariela Carolina LOPE-NAVARRETE³, Jesús Alberto BARRON-ZAMBRANO³, \\ Pablo DÍAZ-RIVERA ${ }^{4}$, Emmanuel de Jesús RAMÍREZ-RIVERA ${ }^{4,5 *}$
}

\begin{abstract}
The objective of this study was to perform a profile of mineral elements and the relationship of those as markers of geographical origin of artisanal goat cheese from the State of Veracruz, Mexico. In fresh and mature goat cheeses the quantified elements were: heavy (aluminum, arsenic, cadmium, lead), major (calcium, potassium, sodium, magnesium), essential (cobalt, chromium, copper, iron, manganese, selenium, zinc), and others (nickel and strontium). The database using variance analyses and discriminant function analysis was analyzed. Differences $(\mathrm{P}<0.05)$ were found in the contents of elements between fresh and mature cheeses. The content of major, essential and other elements were similar to the results from other investigations. The concentration of arsenic and lead surpassed the limits accepted by international and Mexican standards. Nine elements helped to determine the geographic origin of the goat cheeses.
\end{abstract}

Keywords: artisanal goat cheeses; essential elements; heavy metals; major elements; plasma atomic emission spectroscopy.

Practical Application: Know minerals of Mexican artisanal cheeses and their relationship with the territory.

\section{Introduction}

The artisanal goat cheeses are considered an excellent source of proteins, lipids, vitamins and mineral elements (Mendil, 2006; Moreno-Rojas et al., 2010). Which are the major (i.e. $\mathrm{Ca}, \mathrm{K}, \mathrm{Mg}$ and $\mathrm{Na}$ ), essential (i.e. $\mathrm{Co}, \mathrm{Cu}, \mathrm{Cr}, \mathrm{Fe}, \mathrm{Mn}$ and $\mathrm{Zn}$ ) and elements as $\mathrm{Ni}$ are needed for the proper metabolic functioning of the organism (Sevgi-Kirdar et al., 2015). However, the mineral content in the cheese can be modified by factors such as feeding goats, heat treatment of milk, processing of cheeses (i.e. coagulation, pressing and salting) and the ripening effects caused by the different biochemical reactions (i.e. lipolysis and proteolysis) and modifications of the water content (Almanera et al., 2007). Nevertheless in the context of food security, the chemical safety of artisanal cheeses may be affected by the proximity between goat farms producing artisanal cheeses and urban centers or industries that can contribute to chemical contamination of cheeses by heavy metals such As, $\mathrm{Cd}$ and $\mathrm{Pb}$ (Kodrik et al., 2001; ElSayed-Elham et al., 2011; Osorio et al., 2015; Ozbek \& Akman, 2016).

The consumption of artisanal goat cheeses contaminated with heavy metals can generate harmful effects to human such as neurological problems, cardiovascular toxicity, instability of the central nervous system, interference of the synthesis of the hemo group and osteoporosis (Moreno-Rojas et al. 2010; Elbarbary \& Hamouda, 2013; Ibrahim \& Mehanna, 2015; Sevgi-Kirdar et al.,
2015). In this sense, it was estimated that 1.52 million metric tons of lead were used in the world for various industrial applications in the year 2004 (Tchounwou et al., 2012). In the case of cadmium is a natural constituent of the earth's crust and occurs in soils in concentration of 0.1 to $1.0 \mathrm{mg} \cdot \mathrm{kg}^{-1} \mathrm{dry}$ weight, however, the fertilizers applied to feed crops for animals are another source of supply of this metal (Barbara-Fisher, 2005). While that in the countries of Bangladesh, India, Chile, Uruguay, Taiwan and Mexico the existence of high contents of arsenic in air in the range of 20 to $100 \mathrm{ng} \cdot \mathrm{m}^{-3}$ has been demonstrated (Tchounwou et al., 2012).

Therefore, it is important to apply the geographical origin approach as a measure of food security, traceability, consumer protection and geographical marker of artisanal cheeses (Moreno-Rojas et al., 2010; Nečemer et al., 2016). This approach has been applied in diverse cheeses with Designation of Origin (DO) from Spain (Peláez-Puerto et al., 2004; Almanera et al., 2007; Ledesma et al., 2007; Moreno-Rojas et al., 2010, 2012), Egypt (Osorio et al., 2015) and Slovenia (Nečemer et al., 2016).

The importance of artisanal cheese is increasing both at the international and national due to changes in consumers' lifestyles (Cagri-Mehmetoglu, 2018). The consumption of artisanal cheese per capita in European countries (i.e. Greece, France) is $20 \mathrm{~kg}$ per year. In Mexico, the consumption of this food is $2.1 \mathrm{~kg}$ per

${ }^{1}$ Tecnológico Nacional de México, Instituto Tecnológico de Tuxtepec, Tuxtepec, Oaxaca, México

${ }^{2}$ Tecnológico Nacional de México, Instituto Tecnológico de Mérida, Mérida, Yucatán, México

${ }^{3}$ Facultad de Ingeniería Química, Universidad Autónoma de Yucatán, Mérida, Yucatán, México

${ }^{4}$ Colegio de Postgraduados Campus Veracruz, Tepetates, municipio de Manlio Fabio Altamirano, Veracruz, México

${ }^{5}$ Tecnológico Nacional de México, Instituto Tecnológico Superior de Zongolica, Veracruz, México

*Corresponding author: ejramirezrivera@itszongolica.edu.mx 
year (Cervantes-Escoto \& Villegas-de-Gante, 2014). Currently, the typification of Mexican artisan cheeses has been carried out according to their physicochemical, microbiological, instrumental and sensory characteristics (Cervantes-Escoto \& Villegas-de-Gante, 2014; Ramírez-Rivera et al., 2017). Nevertheless, there is no scientific evidence on the determination of mineral elements in Mexican goat cheeses produced in the central area and highlands of the State of Veracruz. The researches of Ramírez-Rivera et al. $(2017,2018)$ determined the typicality of the goat cheeses of the State of Veracruz in Mexico without considering the analysis of mineral elements present in these cheeses. Veracruz State is considered an important geographical area for the production of fresh and mature artisanal goat cheeses, specifically; places like Coatepec, Pacho Viejo, Perote and Tatatila are those that produce $90 \%$ of these cheeses (Instituto Nacional de Estadística y Geografía, 2007). These cheeses are attached to the territory, they are emblematic of the gastronomic culture of the area, and they are an important source of income for the people involved in their production (Ramírez-Rivera et al., 2017). Therefore, the objective of this study was to perform a profile of mineral elements and the relationship of those as markers of geographical origin of artisanal goat cheese from the State of Veracruz, Mexico.

\section{Materials and methods}

\subsection{Source of the samples and processing of artisanal cheeses}

A total of eight artisanal goat cheeses were analyzed ( $n_{1}=$ four fresh cheeses and $n_{2}=$ four mature cheeses) used in Goat Production Units (GPU) of municipalities as Pacho Viejo, Coatepec, Perote, and Tatatila, in the State of Veracruz in Mexico. These GPU are located in the central mountainous region and the highlands of Veracruz State, where the dominant vegetation are mesophilic mountain forest as oyamel and pine, and xerophilous scrub (Ramírez-Rivera et al., 2018). The cheeses of this research were chosen due to the following reasons: 1) the GUPs were affiliated with the nonprofit Goat Species Product-System of Veracruz; 2) the cheeses are made by hand;
3) cheeses fulfilled with the microbiological limits indicated by the Official Mexican Standards and have great acceptance by consumers (Ramírez-Rivera et al., 2017; Ramírez-Rivera et al., 2018). Also, the number of samples analyzed in this research was adequate and similar to those analyzed by Ledesma et al. (2007) and Ibrahim \& Mehanna (2015).

The cheeses are made with milk from Alpine and Saanen goats (3.5 years old on average), milked manually in the dry season (May month). The quality of goat milk obtained present the microbiological parameters proposed by the Official Mexican Standards (Ramírez-Rivera et al., 2018). The characteristics of the goat farms, milk production and places of location are shown in Table 1. The manufacturing stages for the artisanal goat cheese were as follows: 1 ) the goats were milked by hand, and the milk was pasteurized at $63{ }^{\circ} \mathrm{C}$ for $30 \mathrm{~min}$, and was then cooled to $37^{\circ} \mathrm{C}$; 2) A commercial curdling agent was added with a strength of coagulation $=1: 10,000$; equivalent to $110 \mathrm{IMCU} \mathrm{mL}^{-1}$ (Cuamex Company, Mexico) in a proportion of $30 \mathrm{~mL} \cdot 100 \mathrm{~L}^{-1}$; after 45 minutes, the curd was cut; 3 ) the curd was molded in polyvinylchloride (PVC) cylinders and later, a stainless steel press was used to apply a pressure of $2 \mathrm{~kg}$ of force $\mathrm{kg}^{-1}$ of cheese for $\left.7 \mathrm{~h} ; 4\right)$ the cheeses were submerged in a brine solution $(28 \%$ of $\mathrm{NaCl})$ and laid at room temperature $\left(18 \pm 2{ }^{\circ} \mathrm{C}\right)$ for two days to obtain the fresh cheeses. The matured cheeses were obtained through inoculation by spraying the strain Penicillum candidum (Choozit ${ }^{\mathrm{m}}$ PC-VB, commercial brand Danisco, Dupont Mexico) on the fresh cheeses, which were then stored in wooden cavas for seven weeks at a temperature of $18 \pm 2{ }^{\circ} \mathrm{C}$ and a relative humidity of $80-85 \%$.

\subsection{Conditioning the samples and analytical process}

The samples were digested using a calcination method due to the high content of ethereal extract. Two $g$ of each cheese were weighed and then charred at $550^{\circ} \mathrm{C}$ in a muffle furnace (Felisa, FE-340, Feligneo, Mexico) for $5 \mathrm{~h}$ (method 935.42 Association

Table 1. Characteristics of the Goat Production Units, milk production and location places.

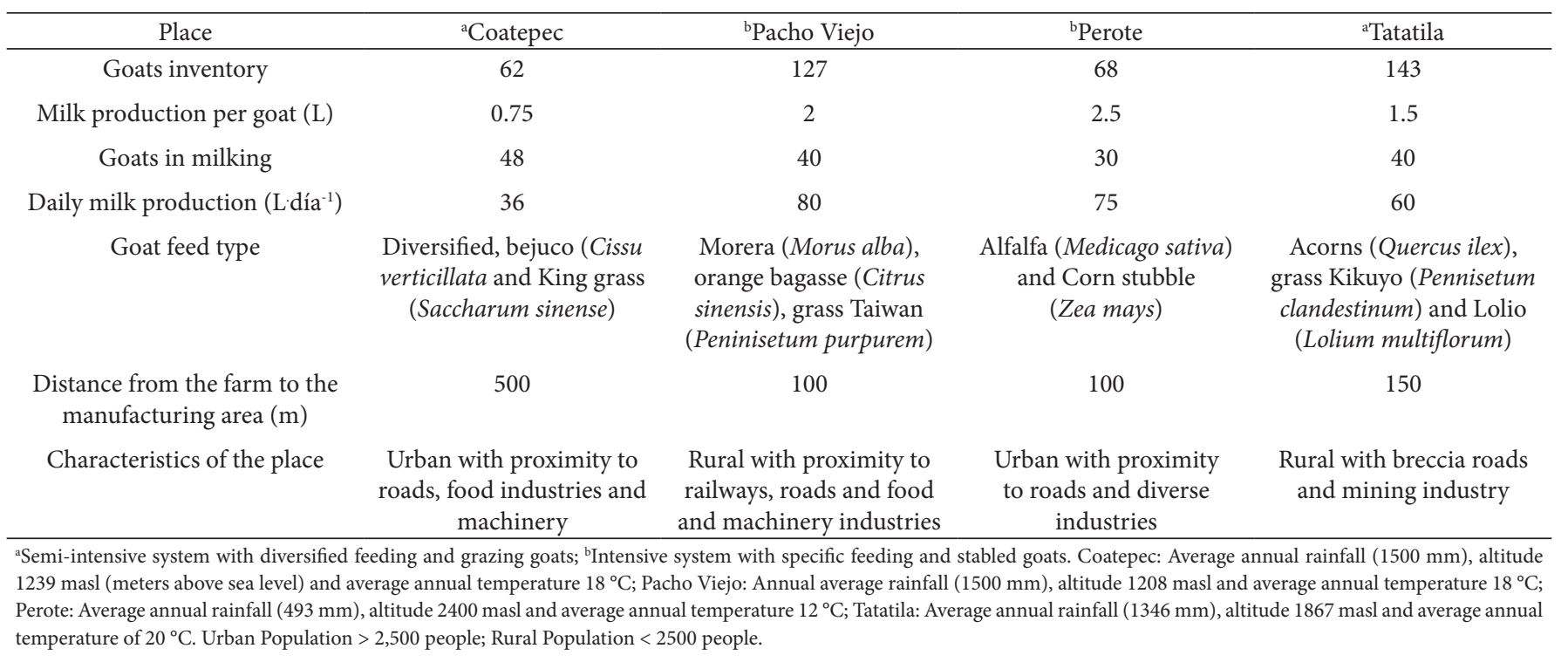


of Official Analytical Chemists, 2012). Later, the ashes were dissolved in $4 \mathrm{~mL}$ of $\mathrm{HCl} 3 \mathrm{~mol} \cdot \mathrm{L}^{-1}$ and diluted at $25 \mathrm{~mL}$ with $\mathrm{HNO}_{3}$ at $1 \%$. The $\mathrm{HCl}$ in form supra pure and $\mathrm{HNO}_{3}$ (at $65 \%$ ) were obtained (Merck, Darmstadt, Germany). The concentrations of the heavy metals as aluminum $(\mathrm{Al})$, arsenic $(\mathrm{As})$, cadmium $(\mathrm{Cd})$, and lead $(\mathrm{Pb})$, majority elements as calcium $(\mathrm{Ca})$, potassium $(\mathrm{K})$, sodium $(\mathrm{Na})$, and magnesium $(\mathrm{Mg})$, essential elements as cobalt $(\mathrm{Co})$, chromium $(\mathrm{Cr})$, copper $(\mathrm{Cu})$, iron $(\mathrm{Fe})$, manganese $(\mathrm{Mn})$, selenium $(\mathrm{Se})$, and zinc $(\mathrm{Zn})$, and other elements as nickel $(\mathrm{Ni})$ and strontium $(\mathrm{Sr})$ were quantified using a microwave induced Plasm Atomic Emission Spectroscopy (MP-AES, 4200MP-AES, Agilent Technologies, New Castle, Delawere, USA) connected to a nitrogen generator (Peak Genius 3055, Agilent Technologies, New Castle, Delawere, USA). The operation conditions (nebulizer flow and wave length per element) of the MP-AES equipment are shown in Table 2. The multielement solutions were diluted in a range of concentrations of $0.1-5 \mathrm{mg} \cdot \mathrm{L}^{-1}$ for $\mathrm{Al}, \mathrm{As}, \mathrm{Cd}$, $\mathrm{Co}, \mathrm{Cu}, \mathrm{Cr}, \mathrm{Mn}, \mathrm{Ni}, \mathrm{Pb}, \mathrm{Sr}, \mathrm{Se}$, and $\mathrm{Zn}$ and concentrations of $0.1-10 \mathrm{mg} \cdot \mathrm{L}^{-1}$ for $\mathrm{Ca}, \mathrm{Fe}, \mathrm{K}, \mathrm{Mg}$, and $\mathrm{Na}$. The calibration curves (coefficient of correlation $\mathrm{R}^{2}=0.99$ per element) using multielement standard solutions (Agilent Technologies, Delawere, U.S.A.) were carried out for $\mathrm{Al}, \mathrm{As}, \mathrm{Cd}, \mathrm{Co}, \mathrm{Cu}, \mathrm{Cr}, \mathrm{Mn}, \mathrm{Ni}, \mathrm{Pb}, \mathrm{Sr}, \mathrm{Se}$, and $\mathrm{Zn}\left(50 \mathrm{mg} \cdot \mathrm{L}^{-1}\right)$ and $\mathrm{Ca}, \mathrm{Fe}, \mathrm{K}, \mathrm{Mg}$, and $\mathrm{Na}\left(500 \mathrm{mg} \cdot \mathrm{L}^{-1}\right)$ The determinations were carried out six times for reproducible and reliable results (Osorio et al., 2015).

\subsection{Statistical analysis}

The data were collected in a matrix of dimensions $\left(J^{*} M\right)$ $K$, where $J=8$ cheeses ( 2 types of cheeses and 4 places), $M=6$ repetitions and $K=17$ elements for a total 816 data. Descriptive analysis and central tendency (mean and standard deviation), as well as one-way (type of cheese) analysis of variance (ANOVA) and a Tukey post hoc test to determine significant difference in the minerals concentration between both types of cheeses were applied (Peláez-Puerto et al.,2004; Moreno-Rojas et al.,2012).

Later, a Discriminating Analysis (DA) method stepwise procedure was used, this analysis was performed three times one for each qualitative variable (type of cheese, fresh cheese and matured cheese) to determine the geographic origin of the cheeses based on the quantified elements (Moreno-Rojas et al.,
2010; Osorio et al., 2015). The DA assesses new synthetic variables called "discriminant functions", are linear combinations of the selected principal components, and allow a better separation of the centers of gravity of the considered groups (Karoui et al., 2007).

In addition, the following statistical indicators derived stepwise, were interpreted: 1 ) Wilk's Lambda test $(\lambda)$ and probability values (P) to determine the significance of discriminant functions. Wilks' lambda is computed as the ratio of the determinant of within-group variance/covariance matrix to the determinant of the total variance/covariance matrix, where values near to 0 indicate a high discriminatory power (Shintu \& Caldarelli, 2006); 2) the distances of Mahalanobis and confidence ellipses with a confidence level of $95 \%$ were used to determine the separation between the cheeses in the factorial plane of the DA. In this sense, it was considered that the greater distance is the difference between the cheeses; 3 ) the percentage (\%) of classification was applied to check the discriminatory capacity of the model generated based on the content of elements (Almanera et al., 2007; Moreno-Rojas et al., 2010 and 2012).

The descriptive statistics, central tendency, ANOVA and Tukey test were carried out using the software STATGRAPHIC PLUS version 5.2 (Statistical Graphics Corp, U.S.A). The DA was carried out using the Proc candisc procedure (SAS Institute Inc., 2002).

\section{Results and discussion}

\subsection{Effect of maturation on the mineral concentration of cheeses}

The concentrations of the elements for each type of artisanal goat cheese are shown in Table 3. Differences $(P<0.05)$ between the fresh and matured cheeses for the following elements were found: $\mathrm{Pb}$ and $\mathrm{Al}$ (heavy), $\mathrm{K}$ and $\mathrm{Na}$ (Major), $\mathrm{Mn}$, Se and $\mathrm{Zn}$ (essential), and $\mathrm{Sr}$ (other elements). The matured cheeses showed the highest concentrations $(\mathrm{P}<0.05)$ of $\mathrm{Pb}, \mathrm{Al}, \mathrm{Mn}, \mathrm{Se}, \mathrm{K}$, and $\mathrm{Na}$, which may be attributed to changes in the protein fraction by dehydration related with the maturity process, and the retention of elements in the casein network (Peláez-Puerto et al., 2004; Herrera-García et al., 2006).

Table 2. Conditions for operating the Plasma Atomic Emission Spectroscopy equipment.

\begin{tabular}{|c|c|c|c|c|c|}
\hline Type of element & $\begin{array}{c}\text { Nebulizer flow } \\
\left(\mathrm{L} \cdot \mathrm{min}^{-1}\right)\end{array}$ & $\begin{array}{l}\text { Wave length } \\
(\mathrm{nm})\end{array}$ & $\begin{array}{l}\text { Type of } \\
\text { element }\end{array}$ & $\begin{array}{c}\text { Nebulizer flow } \\
\left(\mathrm{L} \cdot \mathrm{min}^{-1}\right)\end{array}$ & $\begin{array}{c}\text { Wave length } \\
\text { (nm) }\end{array}$ \\
\hline Heavy & & & Essential & & \\
\hline $\mathrm{Pb}$ & 0.40 & 405.781 & Co & 0.70 & 340.512 \\
\hline $\mathrm{Cd}$ & 0.55 & 228.802 & $\mathrm{Cr}$ & 0.95 & 425.433 \\
\hline $\mathrm{Al}$ & 1 & 396.152 & $\mathrm{Fe}$ & 1 & 371.993 \\
\hline $\mathrm{Mg}$ & 0.75 & 285.213 & $\mathrm{Zn}$ & 0.45 & 213.857 \\
\hline K & 0.95 & 766.491 & Other elements & & \\
\hline \multirow[t]{2}{*}{$\mathrm{Na}$} & 0.90 & 588.995 & $\mathrm{Ni}$ & 0.70 & 352.454 \\
\hline & & & $\mathrm{Sr}$ & 0.55 & 407.771 \\
\hline
\end{tabular}

The values of the correlation coefficient of the curves per element were $R^{2}=0.99$. 
The concentration of the major elements as a $\mathrm{Ca}$ and $\mathrm{Mg}$ were similar $(\mathrm{P}<0.05)$ between both cheeses types; this effect was also observed by Herrera-García et al. (2006) and González-Martin et al. (2009) in fresh and matured goat cheeses. Respect to content of essential elements, it was found that the concentrations of $\mathrm{Cu}, \mathrm{Cr}$ and $\mathrm{Fe}$ were similar $(\mathrm{P}>0.05)$ between both types of cheeses (Table 3). This result is due to the metals mentioned above becoming concentrated during the dehydration of the cheeses caused by the ripening process (Peláez-Puerto et al., 2004; Herrera-García et al., 2006). While the high Zn content in the fresh cheeses may be due to the association of this element with albumins and other proteins in the whey and possibly to its presence in the milk (Peláez-Puerto et al., 2004; Nečemer et al., 2016). That is, there is a migration of $\mathrm{Zn}$ from the insoluble mycelium fraction to the soluble one causing this metal to be lost in the residual serum; this effect is generated by the decrease in $\mathrm{pH}$ during the cheese's maturation (Macedo \& Malcata, 1997). According to Ibrahim \& Mehanna (2015) the draining of whey curd is another factor that contributes to the loss of $\mathrm{Zn}$.

Only the Cd, Co, and Ni none were found in any type of cheese, probably due to their concentrations being below the established detection limits (Moreno-Rojas et al., 2010).

\subsection{Heavy elements}

The concentrations of $\mathrm{As}$ and $\mathrm{Pb}$ in both cheeses types exceed the permitted limit of $0.2 \mathrm{mg} \cdot \mathrm{kg}^{-1}$ (As) and $0.020-0.5 \mathrm{mg} \cdot \mathrm{kg}^{-1}(\mathrm{~Pb})$ indicated in international standards CODEX-STAN 193 (Food and Agriculture Organization, 1995), Commission Regulation (EC)-1881 (European Union, 2006) and NOM-243-SSA1-2005 (México, 2010). This same situation has been reported by Mendil (2006), who found $\mathrm{Pb}$ values in a range of $0.31-1.2 \mathrm{mg} \cdot \mathrm{kg}^{-1}$ in different artisanal cheeses in Turkey. Likewise, Shahbazi et al. (2016) reported values of $0.0145 \mathrm{mg} \cdot \mathrm{kg}^{-1}$ for $\mathrm{Pb}$ in cheeses produced in different regions of Iran. The high concentrations of $\mathrm{Pb}$ and As could be due to the environmental pollution produced in the urban areas near the places of production of artisanal cheeses (Kodrik et al., 2001). Nevertheless Ibrahim \& Mehanna (2015) mentioned that the high concentration of $\mathrm{Pb}$ in the cheese may be because these products are exposed in the tinned cans and by the liberation of this metal by effect of the temperature used in the process of elaboration of the cheeses. Osorio et al., (2015) commented that the plant-animal-milk relationship is one of the main routes for the contamination of cheeses by heavy metals due to the use of pesticides and fertilizers.

In contrast, the $\mathrm{Al}$ content obtained was below those found by and Ibrahim \& Mehanna (2015), who reported values of $8.20 \mathrm{mg} \cdot \mathrm{kg}^{-1}$ in Domiati goat cheeses from Egypt. The low $\mathrm{Al}$ concentration in this study may be due to the direct contact with the utensils used for cheese processing (Güller, 2007). The concentration of Al found in this investigation was 2.16 and $4.01 \mathrm{mg} \cdot \mathrm{kg}^{-1}$ for fresh and ripened cheeses, respectively, which is below the maximum allowed limit $\left(15 \mathrm{mg} \cdot \mathrm{kg}^{-1}\right)$ proposed in the Commission Regulation (EC)-1881 (European Union, 2006).

\subsection{Major elements}

The high content of major elements, mainly $\mathrm{Na}$, could be due to the use of the method of salting by immersion (brine at $28 \%$ ) applied in the production of cheese in this study; this salting method produces a diffusion of the $\mathrm{NaCl}$ inside the cheese's matrix, favoring the release of water and a greater concentration of these elements (Moreno-Rojas et al., 2012). Due to the concentrations of $\mathrm{Na}$ found in the cheeses of this

Table 3. Mean values per element and types of cheeses.

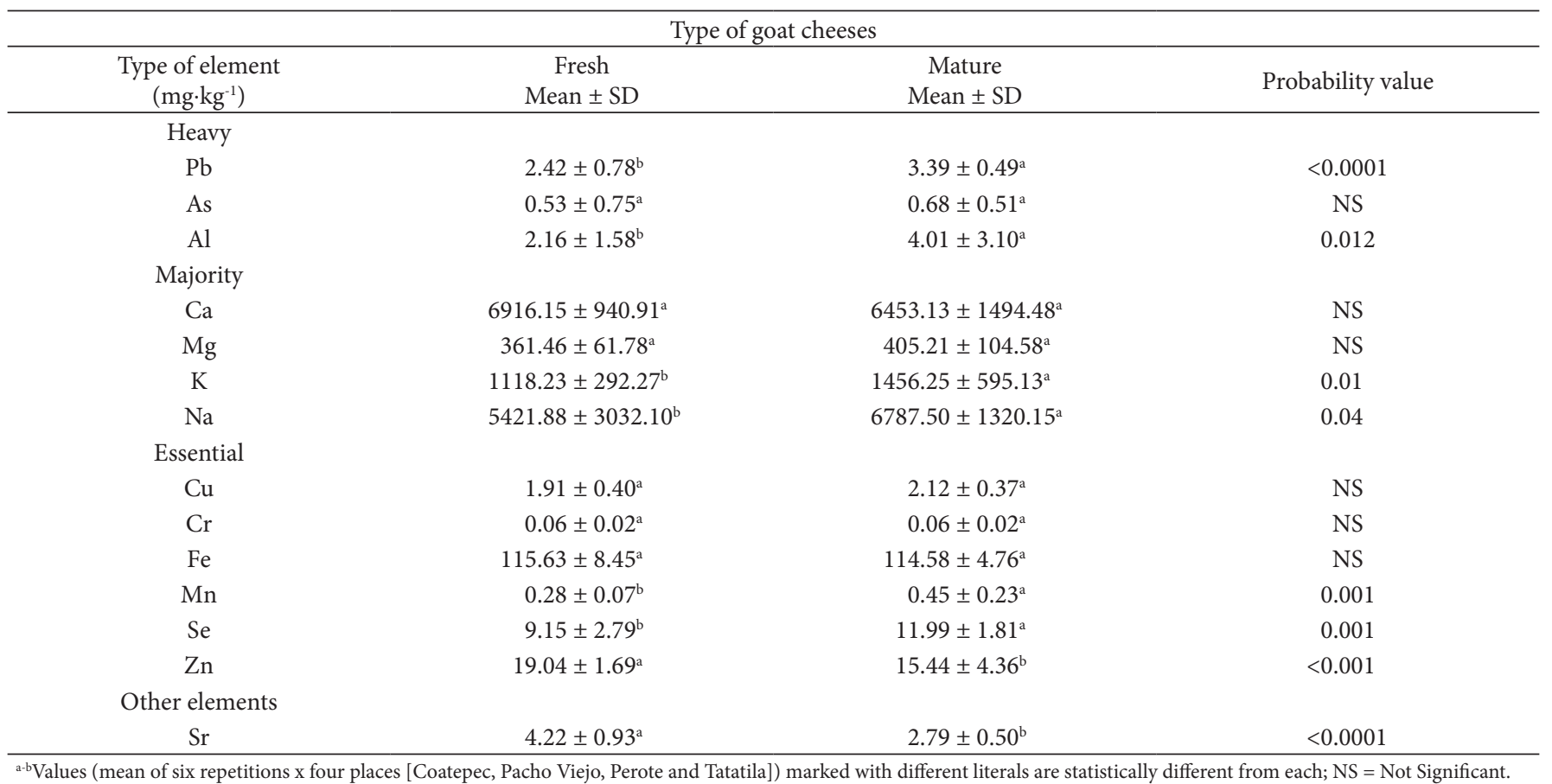


research, this type of food is recommended for people with skeletal, neurological problems and non-hypertensive (Macedo \& Malcata, 1997; Bona et al., 2010). Only the elements Ca and $\mathrm{Mg}$ were similar $(\mathrm{P}<0.05)$ between both cheeses types; this is due to the fact that $\mathrm{Ca}$ and $\mathrm{Mg}$, when linked to the solid phase of the cheese, have a lower degree of mobility and the loss of these metals is minimal between fresh and ripened cheese (Moreno-Rojas et al., 1994); This effect was also observed by Herrera-García et al. (2006) and González-Martin et al. (2009) in fresh and matured Spanish goat cheeses. The above indicates that the cheeses of this research had a production process similar to that used for the manufacture of Spanish cheeses, where the process is characterized as an enzymatic coagulation, salted and drained (Fresno et al., 1995).

The values obtained for the major elements are within the ranges reported in other investigations; Moreno-Rojas et al. (2010) obtained concentrations in the range of 1,536 - 9,389; $920-1,291 ; 174-826$ and $1,002-8,927 \mathrm{mg} \cdot \mathrm{kg}^{-1}$ for $\mathrm{Ca}, \mathrm{K}$, $\mathrm{Mg}$, and $\mathrm{Na}$, respectively in 22 different artisanal cheeses with Designation of Origin (DO) produced in Spain. Osorio et al. (2015) evaluated cheeses from Egypt and found ranges of concentrations between $6,583-7,569 ; 1,152-2,039 ; 236-350$ and 7,952 - 16,193 mg.kg-1 for $\mathrm{Ca}, \mathrm{K}, \mathrm{Mg}$, and $\mathrm{Na}$, respectively.

\subsection{Essential elements}

The contents of $\mathrm{Cu}, \mathrm{Cr}$ and $\mathrm{Fe}$ might be explained by contamination spread from the containers during the process of transporting and processing cheese milk, where the $\mathrm{Cr}$ is frequently used in the production of stainless steel materials (Ibrahim \& Mehanna, 2015; Sevgi-Kirdar et al., 2015). The concentrations of $\mathrm{Cu}, \mathrm{Fe}$, and $\mathrm{Zn}$ found in this study are higher than those reported by Sevgi-Kirdar et al. (2015) these authors determined concentrations of $\mathrm{Cu}, \mathrm{Fe}$, and $\mathrm{Zn}$ in Tulum cheeses from the city of Kargi, District of Corum, Turkey, and reported values of $\mathrm{Cu}=0.29 ; \mathrm{Fe}=0.20$, and $\mathrm{Zn}=0.28 \mathrm{mg} \cdot \mathrm{kg}^{-1}$ in fresh cheeses, while for matured cheeses, these levels were of $\mathrm{Cu}=0.39, \mathrm{Fe}=0.41$, and $\mathrm{Zn}=0.33 \mathrm{mg} \cdot \mathrm{kg}^{-1}$. The values for Se in this research were lower compared to those obtained by Herrera-García et al. (2006), who reported 72.9 and $152 \mathrm{mg} \cdot \mathrm{kg}^{-1}$ in fresh and matured cheeses from Canary Islands, Spain, respectively. The values for $\mathrm{Cr}$ and $\mathrm{Mn}$ were greater and lower, respectively, to those reported by Ibrahim \& Mehanna, (2015), who obtained concentrations of 0.026 and $1.39 \mathrm{mg} \cdot \mathrm{kg}^{-1}$ of $\mathrm{Cr}$ and $\mathrm{Mn}$ in Domiati cheeses from Egypt. According to the values found in the essential elements, Bou-Khouzam et al. (2011) and Sevgi-Kirdar et al. (2015) mentioned that the daily intake of $\mathrm{Cu}, \mathrm{Fe}, \mathrm{Mn}, \mathrm{Zn}$ in adults must be within a range of $3-5,8-15,2-5$, and $11\left(\mathrm{mg} \cdot\right.$ day $\left.^{-1}\right)$, respectively; in the case of $\mathrm{Cr}$ and $\mathrm{Se}$, daily recommended intake is of 0.04 and $0.055 \mathrm{mg} \cdot \mathrm{day}^{-1}$, respectively, according to Monsen (2000). According to the data obtained, a healthy adult can cover a part of his daily requirements of essential minerals by eating these artisanal cheeses (Sevgi-Kirdar et al., 2015).

\subsection{Other elements}

In the case of others elements such as $\mathrm{Sr}$, the values found are lower than those reported by Ibrahim \& Mehanna, (2015) of $13 \mathrm{mg} \cdot \mathrm{kg}^{-1}$ in Domiati cheese of Egypt; Osorio et al. (2015) obtained Sr concentrations between $6.74-25.15 \mathrm{mg} \cdot \mathrm{kg}^{-1}$ in Halloumi cheeses of Cyprus. The presence of Sr in the cheeses in this study can be related to chemical contamination, due to the use of agricultural fertilizers, since different elements, including Sr, are spread by factors such as the wind, dust, or water into the goat feed (Güller, 2007; Ibrahim \& Mehanna, 2015). The differences with concentrations found in other investigations could be due to factors such as the time of production of the cheeses, animal genetic factors, the type of feed, and the protein and fat contents in the milk used (Güller, 2007; Ozbek \& Akman, 2016).

\subsection{Geographical origin of artisanal cheeses: Discriminating Analysis (DA) for type of cheese}

The two first discriminating functions that explain 100\% of the variation between fresh and matured cheeses is shown in Figure 1a. The first discriminating function showed a clear separation between both types of cheeses ( $\lambda$ of Wilk's $=0.025, P<0.0001$ ) and this was confirmed by the value of Mahalanobis $=220.43$ $(\mathrm{P}<0.001)$.

The results of the stepwise method indicated that in nine elements ( $\mathrm{Al}, \mathrm{K}, \mathrm{Mg}, \mathrm{Mn}, \mathrm{Na}, \mathrm{Pb}, \mathrm{Se}, \mathrm{Sr}$, and $\mathrm{Zn}$ ) out of the 17 elements can be considered markers of the geographic origin of the cheeses of the State of Veracruz. Where the Sr and Zn were the markers of fresh cheese and the rest of the elements ( $\mathrm{Al}, \mathrm{K}, \mathrm{Mg}, \mathrm{Mn}, \mathrm{Na}, \mathrm{Pb}$ and $\mathrm{Se}$ ) were the markers of matured cheeses (Figure 1b).

This result agrees with other investigations that used the same multivariate technique and stepwise procedure. For example, Peláez-Puerto et al. (2004) determined the elements Na, Zn, and Se as markers of the origin of the goat cheeses produced in the Canary Islands, Spain. Likewise, Almanera et al. (2007) found that the elements as $\mathrm{Ca}, \mathrm{Cu}, \mathrm{K}, \mathrm{Fe}, \mathrm{Na}, \mathrm{P}$, and $\mathrm{Zn}$ were indicators of the originality of the Majorero goat cheeses from Spain. On the other hand, Moreno-Rojas et al. $(2010,2012)$ found that some elements such as $\mathrm{K}, \mathrm{Mg}, \mathrm{Mn}, \mathrm{Na}$, and $\mathrm{Zn}$ helped distinguish different cheeses from the north and south of Spain. Meanwhile, Osorio et al. (2015) found that only three elements (K, Mn, and $\mathrm{Sr}$ ) are markers of geographic authenticity of Halloumi cheese from Egypt. Nečemer et al. (2016) observed the elements $\mathrm{P}, \mathrm{S}, \mathrm{K}, \mathrm{Cl}, \mathrm{Ca}$, and $\mathrm{Zn}$ as distinctive elements of geographic origin of cheeses made from cow, goat, and sheep milks in Slovenia.

\subsection{Geographical origin of artisanal cheeses: Discriminating Analysis (DA) for fresh cheese and matured cheese}

The two first discriminating functions that explain $92.45 \%$ of the variation between fresh goat cheeses $(\lambda$ of Wilk's $<0.3$, $\mathrm{P}<0.0001$ ), as in shown in Figure 2a. The first discriminating function showed a clear separation between the first four geographical areas of production of fresh cheeses, where the Tatatila and Coatepec cheeses were differentiated from the Pacho Viejo and Perote fresh cheeses. This separation is indicated by the distances of Mahalanobis Tatatila-Coatepec $(17,102 ; \mathrm{P}<0.0001)$, Tatatila-Pacho Viejo $(22,711 ; \mathrm{P}<0.0001)$, Tatatila-Perote $(22,829 ; \mathrm{P}<0.0001)$, Coatepec-Pacho Viejo 

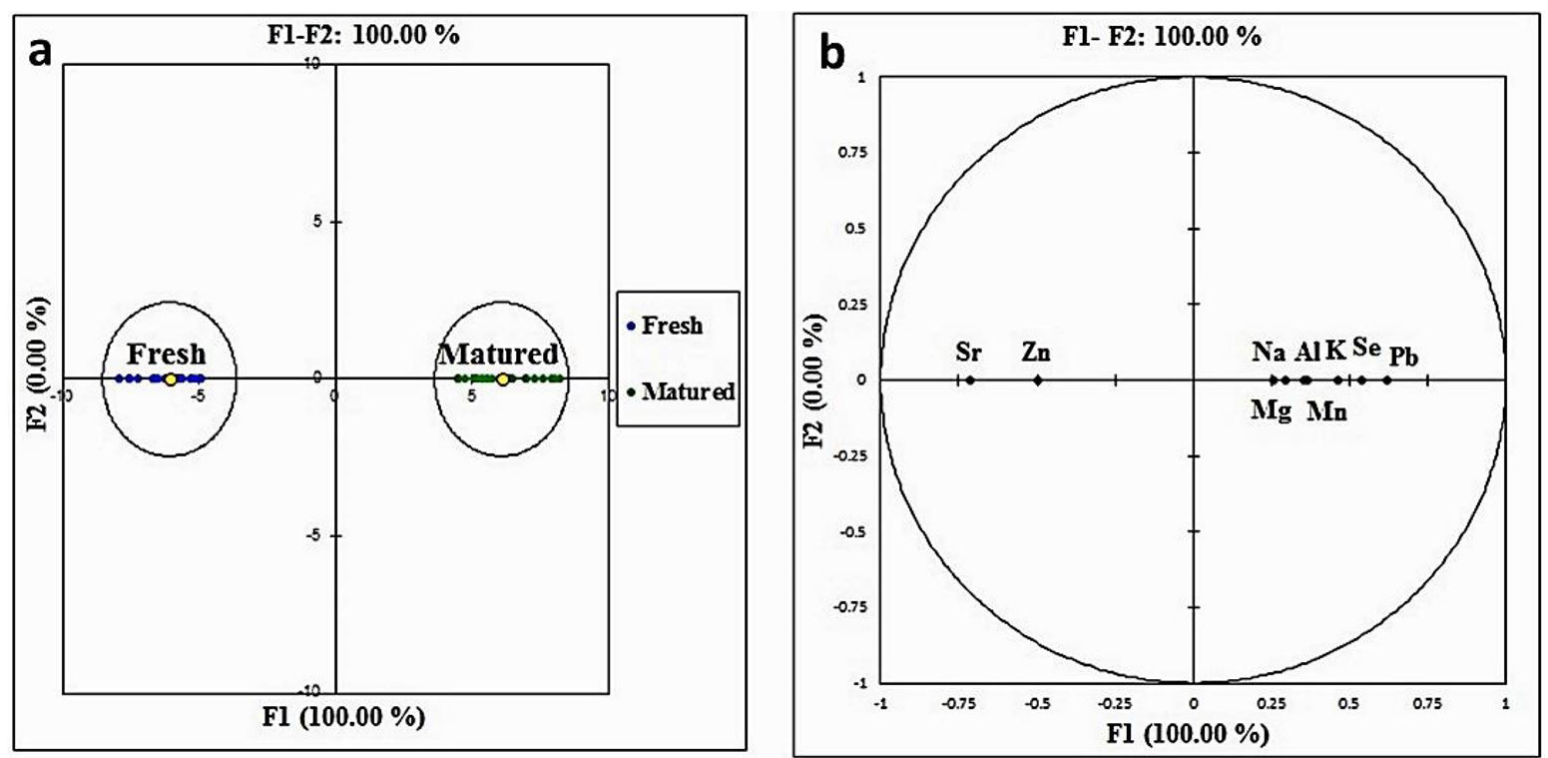

Figure 1. a) Discriminatory Analysis for the qualitative variable type of cheeses; b) elements in the discriminating factorial plane. Non-overlapping confidence ellipses (a confidence level of 95\%) indicate differences between cheeses.
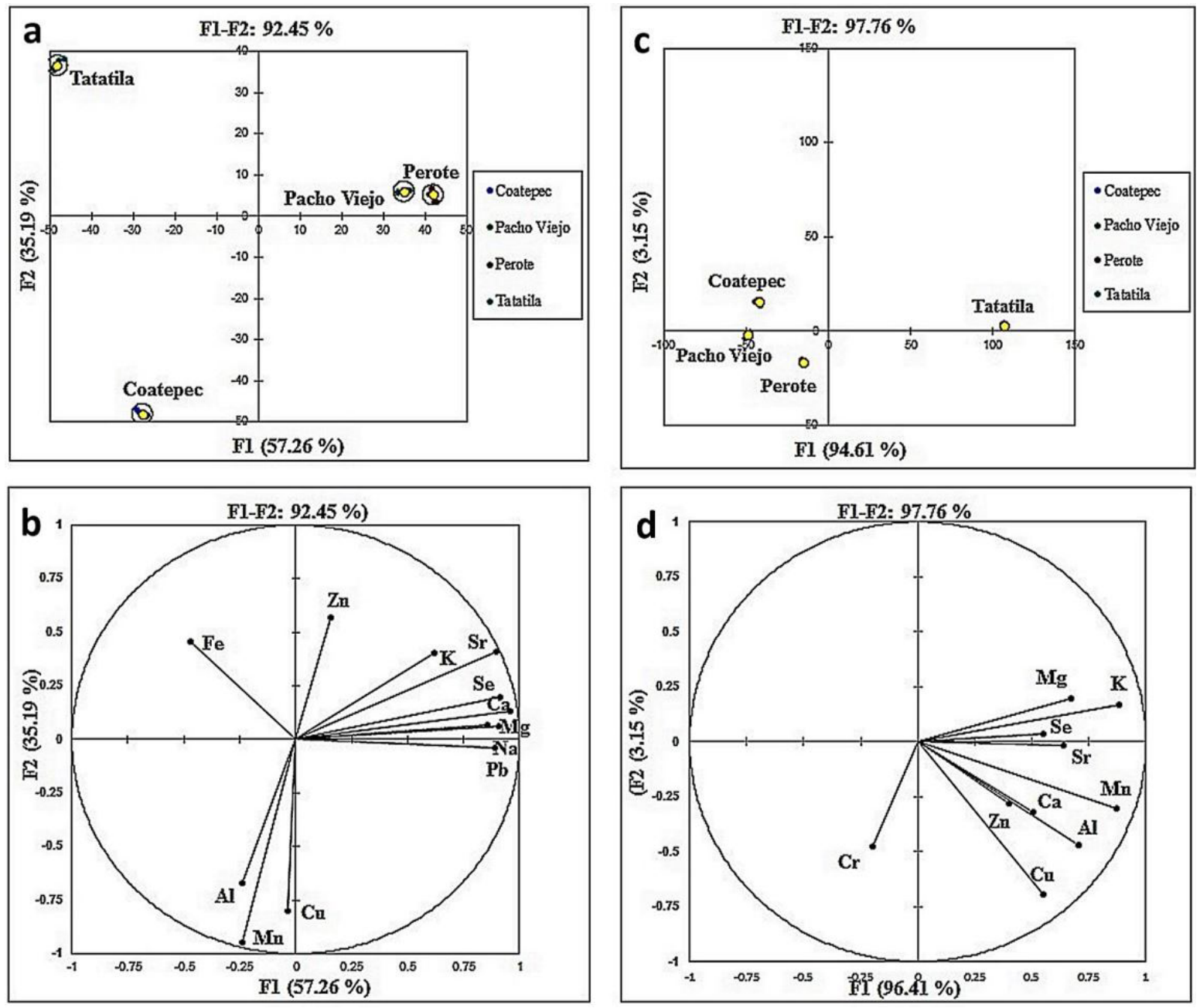

Figure 2. a) Discriminatory Analysis for the qualitative variable fresh cheeses; b) elements of the fresh cheeses in the discriminating factorial plane; c) Discriminatory Analysis for the qualitative variable mature cheeses; d) elements of the mature cheeses in the discriminating factorial plane. Non-overlapping confidence ellipses (a confidence level of 95\%) indicate differences between cheeses. Coatepec, Pacho Viejo, Perote and Tatatila are the producing places of artisanal cheeses. 
$(20,571 ; \mathrm{P}<0.0001)$ and Coatepec-Perote $(17,102 ; \mathrm{P}<0.0001)$. The reason for the distances mentioned was due to the difference of elements that characterize the cheeses (Figure 2b). In this sense, the fresh cheeses of Pacho Viejo and Perote showed high contents of $\mathrm{Ca}, \mathrm{K}, \mathrm{Mg}, \mathrm{Na}, \mathrm{Pb}, \mathrm{Se}, \mathrm{Sr}$ and $\mathrm{Zn}$. In the fresh cheese of Coatepec predominated the elements $\mathrm{Al}, \mathrm{Cu}$ and $\mathrm{Mn}$ while the Tatatila fresh cheese had high content of Fe. Although the cheeses were elaborated under the same manufacturing protocol, the differences shown in the mineral content could be due to the variations in the milk composition caused by the different metabolic rates of the animals influenced by the physiological state and the different environmental temperatures of the sites where are the GPU's (Macedo \& Malcata, 1997). The two first significant discriminating functions (Wilk's $\lambda<0.3 ; \mathrm{P}<0.0001$ ) explain $97.76 \%$ of the variance between matured goat cheeses as in shown in Figure 2c. Regarding the first discriminating function, it was observed that the matured cheeses produced in the geographic region of Tatatila stand out significantly from the rest of the matured cheeses. The Mahalanobis distances found indicated these differences: Coatepec-Tatatila $(5,539 ; \mathrm{P}<0.0001)$, Pacho Viejo-Tatatila $(6,678 ; \mathrm{P}<0.0001)$, Perote-Tatatila $(4,189 ; \mathrm{P}<0.0001)$.

The differences described above between matured cheese of Tatatila and the rest of the cheeses were because this cheese had the high contents of $\mathrm{Al}, \mathrm{Ca}, \mathrm{Cu}, \mathrm{K}, \mathrm{Mn}, \mathrm{Mg}, \mathrm{Se}, \mathrm{Sr}$ and $\mathrm{Zn}$ while the rest of the matured cheeses predominated $\mathrm{Cr}$ (Figure 2d). The diversity of mineral elements of Tatatila cheese could be due to the diversified feeding (semi-intensive systems) of grazing goats as well as the proximity of this GPU to the mining industry (Kodrik et al., 2001; Ledesma et al., 2007, González-Martin et al., 2009). The content of Cr in the rest of the cheeses could be caused because the GPUs are close to the roads with intense vehicular traffic and mainly to the industries, which release the largest amount of this element to the environment for its subsequent entry into the water and forage crops used for goat feeding (Kodrik et al., 2001; Tchounwou et al., 2012). For both types of cheeses (fresh and matured), a percentage of classification of $100 \%$ was obtained, this result indicated the high discrimination capacity of the model used in function of the content of analyzed elements (Moreno-Rojas et al., 2010).

Therefore, the geographical origins of fresh goat cheeses were explained by the following elements: $\mathrm{Al}, \mathrm{Ca}, \mathrm{Cu}, \mathrm{Fe}, \mathrm{K}, \mathrm{Mn}$, $\mathrm{Mg}, \mathrm{Na}, \mathrm{Pb}, \mathrm{Se}, \mathrm{Sr}$, and $\mathrm{Zn}$. In the same sense, the elements $\mathrm{Al}$, $\mathrm{Ca}, \mathrm{Cu}, \mathrm{Cr}, \mathrm{K}, \mathrm{Mg}, \mathrm{Mn}, \mathrm{Se}, \mathrm{Sr}$, and $\mathrm{Zn}$ are considered markers of geographical origin of matured cheeses.

These results were consistent with Peláez-Puerto et al. (2004), who concluded that the group of elements as $\mathrm{Ca}, \mathrm{Cu}$, $\mathrm{Fe}, \mathrm{K}, \mathrm{Mg}$, and $\mathrm{Zn}$, and the group of elements $\mathrm{Ca}, \mathrm{Fe}, \mathrm{Mg}$, Se, and $\mathrm{Zn}$ were considered as markers of authenticity of fresh and matured cheeses, respectively, from the Canary Islands, Spain. On the other hand, Ledesma et al. (2007) determined that the elements $\mathrm{Ca}$ and $\mathrm{P}$ (related to fresh cheeses) as well as $\mathrm{Ca}, \mathrm{Na}, \mathrm{Mg}, \mathrm{Cu}, \mathrm{Se}$, and $\mathrm{Zn}$ (related to mature cheeses) were indicators of the geographic authenticity of Palmero cheeses with a Protected DO.

\section{Conclusion}

The concentration of heavy metals as $\mathrm{As}$ and $\mathrm{Pb}$ exceeds the limits established by Mexican and international regulations, which may be a potential risk for consumers, the causes of which must be tackled by producers. Likewise, the concentrations of heavy metals found highlight the importance of applying studies to find the source of origin of these metals. In the nutritional aspect, eating these artisanal cheeses helps cover the necessary requirements of minerals of a healthy person. According to the results obtained by the $\mathrm{DA}$, only nine elements ( $\mathrm{Al}, \mathrm{K}, \mathrm{Mg}, \mathrm{Mn}$, $\mathrm{Na}, \mathrm{Pb}, \mathrm{Se}, \mathrm{Sr}$, and $\mathrm{Zn}$ ) can be used as markers of the geographic origin of the artisanal goat cheeses from the State of Veracruz in Mexico. However, the geographic origin markers for fresh cheeses are $\mathrm{Al}, \mathrm{Ca}, \mathrm{Cu}, \mathrm{Fe}, \mathrm{K}, \mathrm{Mn}, \mathrm{Mg}, \mathrm{Na}, \mathrm{Pb}, \mathrm{Se}, \mathrm{Sr}$, and $\mathrm{Zn}$, and for matured cheeses are $\mathrm{Al}, \mathrm{Ca}, \mathrm{Cu}, \mathrm{Cr}, \mathrm{K}, \mathrm{Mg}, \mathrm{Mn}, \mathrm{Se}, \mathrm{Sr}$, and $\mathrm{Zn}$. The results obtained in this study could be a feedback for the producers of these cheeses in the creation of a quality seal (Collective Trademark or the Designation of Origin) for the Mexican Industrial Property Institute (IMPI), in order to protect these genuine cheeses.

\section{Acknowledgements}

To the National Council for Science and Technology (CONACYT) of Mexico for the PhD scholarship granted to the corresponding author. To the Instituto Tecnológico de Mérida and the Universidad Autónoma de Yucatán for the supporting in the analytical determination of the elements. To the producers of artisanal cheeses of Goat Species Product System of Veracruz (SIPECAV) for the donated cheese samples for the development of the research.

\section{References}

Almanera, F. J., Álvarez, S., Darias, J., Rodríguez, E., Díaz, C., \& Fresno, M. (2007). Efecto de la maduración en la composición mineral de los quesos de cabra majorera. Archivos de Zootecnia, 56(1), 667-671.

Association of Official Analytical Chemists - AOAC. (2012). Official methods of analysis of the Association of Official Analytical Chemists: Ash of cheese (Method 935.42). Gaithersburg: AOAC.

Barbara-Fisher, A. (2005). Heavy metals in the food Chain-Lead, Cadmium and Mercury in foodstuff and population exposures. Proceedings of the Indian National Science Academy, 71(3-4), 109-143.

Bona, E., Santos Ferreira da Silva, S. R., Borsato, D., Monke e Silva, L. H., \& Souza-Fidelis, D. A. (2010). Multicomponent diffusion during Prato cheese ripening: mathematical modeling using the finite element method. Food Science and Technology, 30(4), 955-963. http://dx.doi.org/10.1590/S0101-20612010000400018.

Bou-Khouzam, R., Poh, P., \& Lobinski, R. (2011). Bioaccessibility of essential elements from white cheese, bread, fruit and vegetables. Talanta, 86(30), 425-428. http://dx.doi.org/10.1016/j.talanta.2011.08.049 PMid:22063561.

Cagri-Mehmetoglu, A. (2018). Food safety challenges associated with foods of Turkey. Food Science and Technology, 38(1), 1-12. http:// dx.doi.org/10.1590/1678-457x.36916.

Cervantes-Escoto, F., \& Villegas de Gante, A. (2014). La leche y los quesos artesanales en México. Agricultura, Sociedad y Desarrollo, 11(2), 243-248. 
Elbarbary, H. A., \& Hamouda, A. F. (2013). Variations in some heavy metals level during processing of soft cheese. Journal of Food Measurement and Characterization, 7(4), 194-198. http://dx.doi. org/10.1007/s11694-013-9155-2.

ElSayed-Elham, M., Bradran-Saana, M., Mostafa-Amr, A., \& HammedAhmed, M. (2011). Evaluation of the factors influencing the content and retention of selected heavy metals in milk and some dairy products. International Journal of Dairy Science, 6(6), 305-313. http://dx.doi.org/10.3923/ijds.2011.305.313.

European Union. (2006). Commission Regulation (EC)-1881. Setting maximum levels for certain contaminants in foodstuffs. Brussell: UE. Retrieved from http://eur-lex.europa.eu/legal-content/EN/TXT/PD $\mathrm{F} /$ ?uri=CELEX:32006R1881\&from $=\mathrm{EN}$

Food and Agriculture Organization - FAO. World Health Organization. (1995). CODEX-STAN 193. Norma general del CODEX para los contaminantes y las toxinas presentes en los alimentos y piensos Rome: FAO Retrieved from: http://www.fao.org/fileadmin/user_upload/ livestockgov/documents/CXS_193s.pdf

Fresno, M. J., Prieto, B., Urdiales, R., \& Martin-Sarmiento, R. (1995). Mineral content of some Spanish cheese varieties differentiation by source of milk and by variety from their content of main and trace elements. Journal of the Science of Food and Agriculture, 69(3), 339-345. http://dx.doi.org/10.1002/jsfa.2740690310.

González-Martin, I., Hernández-Hierro, J. M., Revilla, I., Vivar-Quintana, A., Lobos-Ortega, I., \& González-Pérez, C. (2009). Changes in the mineral in cheese of different composition during 6 months of ripening. Czech Journal of Food Sciences, 27(Special Issue 1), S114-S118. http://dx.doi.org/10.17221/1086-CJFS.

Güller, Z. (2007). Levels of 24 minerals in local goat milk, its strained yoghurt and salted yoghurt (tuzlu yogurt). Small Ruminant Research, 71(1-3), 130-137. http://dx.doi.org/10.1016/j.smallrumres.2006.05.011.

Herrera-García, M. I., Peláez-Puerto, P., Fresno-Baquero, M., RodríguezRodríguez, E., Darías-Martín, J., \& Díaz-Romero, C. (2006). Mineral and trace element concentrations of dairy products from goats' milk produced in Tenerife (Canary Island). International Dairy Journal, 16(2), 182-185. http://dx.doi.org/10.1016/j.idairyj.2005.01.011.

Ibrahim, E., \& Mehanna, N. M. (2015). Determination of some minerals and trace elements content in Domiati cheese by ICP-MS after microwave digestion. Indian Journal of Dairy Science, 68(4), 334-340.

Instituto Nacional de Estadística y Geografía - INEGI. (2007). Censos Agropecuarios. Aguascalientes: INEGI. Retrieved from http://www. inegi.org.mx/est/contenidos/proyectos/agro/default.aspx

Karoui, R., Mazerolles, G., Oliver, B. J., Baerdemaeker, J., \& Dufour, E. (2007). Utilisation of mid-infrared spectroscopy for determination of the geographic origin of Gruyère PDO and L'Etivaz PDO Swiss cheeses. Food Chemistry, 105(2), 847-854. http://dx.doi.org/10.1016/j. foodchem.2007.01.051.

Kodrik, L., Wagner, L., Imre, K., Polyak, K. F., Beyensei, F., \& Husveth, F. (2001). The effect of highway on heavy metal content of cow milk and cheese. Hungarian Journal of Industry and Chemistry, 39(1), 15-19.

Ledesma, L., Fresno, M., Álvarez, S., Darias, J., Rodríguez, E., \& Díaz, C. (2007). Cambios de la composición mineral de quesos de cabra en función de la dieta y el cuajo usado. Archivos de Zootecnia, 56(1), 719-723.

Macedo, A. C., \& Malcata, X. F. (1997). Changes of Mineral Concentrations in Serra Cheese during Ripening and Throughout the Cheesemaking Season. Journal of the Science of Food and Agriculture, 74(3), 409-415. http://dx.doi.org/10.1002/(SICI)1097-0010(199707)74:3<409::AIDJSFA821>3.0.CO;2-P.
Mendil, D. (2006). Mineral and trace metal levels in some cheese collected from Turkey. Food Chemistry, 96(4), 532-537. http://dx.doi. org/10.1016/j.foodchem.2005.03.006.

México. Secretaria de Salud. (2010). Norma Oficial Mexicana NOM243-SSA1-2005. Leche, fórmula láctea, producto lácteo combinado y derivados lácteos. Disposiciones y especificaciones sanitarias. Métodos de prueba (23 de junio del 2008). Diario Oficial de la Federación de México.

Monsen, E. R. (2000). Dietary Reference Intakes for Vitamin C, Vitamin E, Selenium, and Carotenoids. Journal of the American Dietetic Association, 100(6), 637-640. http://dx.doi.org/10.1016/ S0002-8223(00)00189-9. PMid:10863565.

Moreno-Rojas, R., Cámara-Martos, F., Sánchez-Segarra, P. J., \& AmaroLópez, M. (2012). Influence of manufacturing conditions and discrimination of Northern Spanish cheeses using multi-element analysis. International Journal of Dairy Technology, 65(4), 594-602. http://dx.doi.org/10.1111/j.1471-0307.2012.00853.x.

Moreno-Rojas, R., Pozo-Lora, R., Zurera-Cosano, G., \& Amaro-López, M. (1994). Calcium, magnesium, manganese, sodium and potassium variations in Manchego-type cheese during ripening. Food Chemistry, 50(4), 373-378. http://dx.doi.org/10.1016/0308-8146(94)90207-0.

Moreno-Rojas, R., Sánchez-Segarra, P. J., Cámara-Martos, F., \& AmaroLópez, M. (2010). Multivariate analysis techniques as tools for categorization of Southern Spanish cheeses: nutritional composition and mineral content. European Food Research and Technology, 231(6), 841-851. http://dx.doi.org/10.1007/s00217-010-1338-z.

Nečemer, M., Potočnik, D., \& Ogrinc, N. (2016). Discrimination between Slovenian cow, goat and sheep milk and cheese according to geographical origin using a combination of elemental content and stable isotope data. Journal of Food Composition and Analysis, 52, 16-23. http://dx.doi.org/10.1016/j.jfca.2016.07.002.

Osorio, M. T., Koidis, A., \& Papademas, P. (2015). Major trace elements in the milk and Halloumi cheese as marker for the authentication of goat feeding regimes and geographical origin. International Journal of Dairy Technology, 68(4), 573-581. http://dx.doi.org/10.1111/14710307.12213.

Ozbek, N., \& Akman, S. (2016). Microwave plasm atomic emission spectrometric determination of $\mathrm{Ca}, \mathrm{K}$, and $\mathrm{Mg}$ in various cheese varieties. Food Chemistry, 192(1), 295-298. http://dx.doi.org/10.1016/j. foodchem.2015.07.011 PMid:26304350.

Peláez-Puerto, P., Fresno-Baquero, M., Rodríguez-Rodríguez, E., Darías-Martín, J., \& Díaz-Romero, C. (2004). Chemometric studies of fresh and semi-hard goats' cheese produced in Tenerife (Canary Islands). Food Chemistry, 88(3), 361-366. http://dx.doi.org/10.1016/j. foodchem.2004.01.048.

Ramírez-Rivera, E. J., Juárez-Barrientos, J. M., Rodríguez-Miranda, J., Díaz-Rivera, P., Ramón-Canul, L. G., Herrera-Corredor, J. A., Hernández-Serrano, M. I., \& Herman-Lara, E. (2017). Typification of a goat fresh cheese of Mexico by path models. Turkish Journal of Veterinary and Animal Sciences, 41(2), 213-220. http://dx.doi. org/10.3906/vet-1605-66.

Ramírez-Rivera, E. J., Ramón-Canul, L. G., Torres-Hernández, G., Herrera-Corredor, J. A., Juárez-Barrientos, J. M., Rodríguez-Miranda, J., Herman-Lara, E., \& Díaz-Rivera, P. (2018). Tipificación de quesos madurados de cabra producidos en la zona montañosa central del estado de Veracruz, México. Agrociencia, 52(1), 15-34.

SAS Institute Inc. (2002). SAS/STAT users guide: Statics (Release 9.4). Cary: SAS Institute.

Sevgi-Kirdar, S., Kose, S., Gun, I., Ocak, E., \& Kursun, O. (2015). Do consumption of Kargi Tulum cheese meet daily requirements for 
minerals and trace elements?. Mljekarstv: Journal for dairy production and processing improvement, 65(3), 203-209. https://doi.org/10.15567/ mljekarstvo.2015.0307

Shahbazi, Y., Ahmadi, F., \& Fakhari, F. (2016). Voltammetric determination of $\mathrm{Pb}, \mathrm{Cd}, \mathrm{Zn}, \mathrm{Cu}$ and Se in milk and dairy products collected from Iran: An emphasis on permissible limits and risk assessment of exposure to heavy metals. Food Chemistry, 192(1), 1060-1067. http://dx.doi.org/10.1016/j.foodchem.2015.07.123 PMid:26304448.
Shintu, L., \& Caldarelli, S. (2006). Toward the Determination of the Geographical Origin of Emmental(er) Cheese via High Resolution MAS NMR: A Preliminary Investigation. Journal of Agricultural and Food Chemistry, 54(12), 4148-4154. http://dx.doi.org/10.1021/ jf060532k PMid:16756340.

Tchounwou, B. P., Yedjou, C. C., Patlolla, A. K., \& Sutton, D. J. (2012). Heavy metals toxicity and the environment. In A. Luch (Ed.), Molecular, Clinical and Environmental Toxicology (Chap. 5, pp. 133-164). Berlin: Springer. http://dx.doi.org/10.1007/978-3-7643-8340-4_6 